\title{
The practice of confession and absolution as an agent of change in a prophetic Pentecostal Church during COVID-19
}

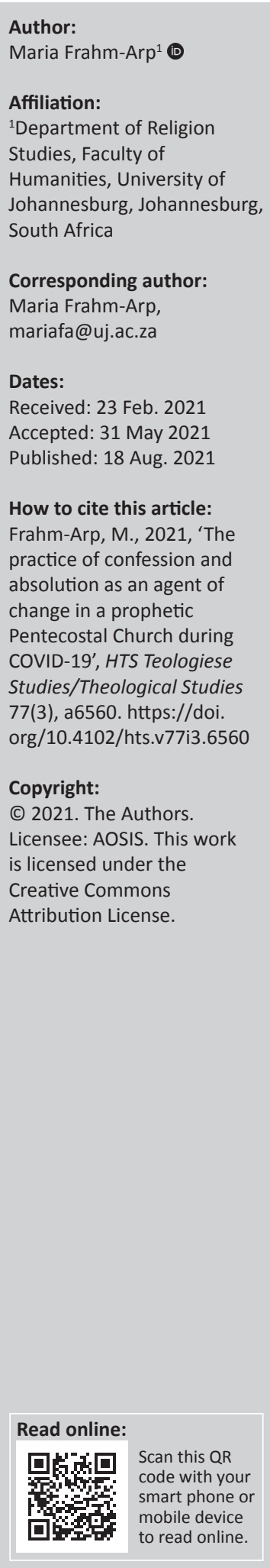

During the coronavirus disease 2019 (COVID-19) pandemic in South Africa, one Prophetic Pentecostal Church, Rabboni Centre Ministries, brought about a marked change in their practice and theology of confession and absolution. Before COVID-19, the Prophet would exorcise the evil spirits that caused sinful behaviour in people and in this way restore them as good Christians acceptable to the congregation. During the COVID-19 lockdown, people could not meet in church and therefore the Prophet changed the practice and theology of confession and absolution. People had to personally identify their own sins and write these down in an email that they sent to the church. Their confessions were then read out, and they were given absolution by the Prophet. During COVID-19, sins were understood as the wrong actions and thoughts of believers, who were personally responsible for their sins. Sins were no longer blamed on Satan. No exorcism followed confessions, rather people were absolved by the Prophet just as people are absolved by priests in mainline churches. In this article, I show that through the act of self-reflection and confession, people are able to take control of their lives and determine their future selves. It also enables people to re-connect to the faith community, the Prophet and God.

Contribution: Unlike the thesis of Weber and Foucault, this does not lead to heightened individualism but rather to a self-reflective individual who is aware both of their individual agency and their self as a 'dividual' being who is connected to other people and spirits.

Keywords: sin; confession; absolution; prophecy; Pentecostalism.

\section{Introduction}

About five months into the coronavirus disease 2019 (COVID-19) pandemic in South Africa, one Prophetic Pentecostal Church ${ }^{1}$ (PPC), Rabboni Christian Ministers (here after Rabboni), introduced a new element to their online services; a space where individuals could publicly confess their sins and receive absolution via one of the pastors from the Prophet-leader. Public confessions of sins are not new in the practice of this church and most PPC. What was new was the theology and practice of the online confessions and absolution established during COVID-19.

In 2002, the South African-born Lesego Daniels started Rabboni in Ga Rankuwa, a peri-urban area outside Pretoria. Before the COVID-19 lockdown that banned religious gatherings in South Africa, this church attracted people from the working and unemployed classes. In January 2014, Prophet Lesego Daniel told his congregation to eat grass and then in September 2014 to drink petrol (ENCA 2014) to bring about healing and prosperity. According to the Prophet, healing was a miracle that God performed via the Prophet in people's lives if they had enough faith and gave money generously to the church. A legal inquiry by the Commission for the Promotion and Protection of the Rights of Cultural, Religious and Linguistic Communities was held in 2015 into the physically harmful practice of drinking petrol and the church stopped this practice. Over the last six years, the prophetic ministry of the Lesego Daniel, who, after receiving a Doctoral Degree from an American University, refers to himself as Professor Lesego Daniel, has grown in popularity enabling the church to build an extensive campus on their premise. Some years before the COVID-19 pandemic, the church set up a television (TV) channel on which it

1.Prophetic Pentecostal Churches refer to the latest form of Pentecostalism that is becoming increasingly popular in Latin America and Africa. These are churches established by leaders who refer to themselves as 'Men of God' and prophets who have extraordinary powers to heal people, drive out demons and promise their followers wealth and success (Frahm-Arp 2020; eds. Kgatle \& Anderson 2020). 
live-streamed services and aired re-runs of previous services. All services were also live streamed on the church's Facebook page.

During COVID-19, the church leader, a self-styled prophet and man of God named Professor Lesego Daniel, spoke about sin as being a contributing factor to why people were suffering and experiencing illness, financial hardship, addiction, spiritual separation from God, broken relationships and generally a sense of chaos and struggle during COVID-19. Understanding sin in this context echoes classical Pentecostal teaching on sin and confession (Alexander 2006). To overcome these difficulties, the Prophet said people needed to be introspective, reflect on precisely what their sins were, then write them down and email them to the church. During the online services, a pastor read out all the emailed confessions and assured confessants that their sins were absolved by the Prophet and forgiven by God. This type of confession and absolution was a new practice in Prophetic Pentecostalism brought about in this particular church as a way to help people cope with the difficulties of COVID-19 and new style of church that had to be invented during lockdown.

Confession in this church was and is understood as owning up to the sins/wrong behaviour and thoughts a person had committed. Before COVID-19, confession was understood as a believer confessing to the sins they committed that the Prophet identified through divine inspiration when the Prophet was prophesying over a believer during a church service. During COVID-19, the practice of confession changed dramatically. People now had to recognise their own sinful behaviour and sinful thoughts and state these in written emails sent to the church. The significant move was that people had to recognise their own sins themselves. The Prophet no longer divinely identified their sins. Before COVID-19, the evil spirit causing the believer to sin was then exorcised by the Prophet, and the sinner was cleansed of evil. During COVID-19, the Prophet no longer exorcised evil spirit but rather said he absolved people of their sins. Absolution was defined by the Prophet as his declaration that the sins of a believer have been forgiven by the Prophet and by God thereby releasing the person from any guilt, obligation or punishment that would otherwise be brought upon them by God. Notable in this was that during the time of this research, sin was understood as resulting from people's own behaviour, where previously it had been attributed to the influence of evil spirits in people's lives. In this discourse of confession and absolution, Prof Daniel preached that individual Christians were responsible for their sinful behaviour and absolution could be given by a 'Man of God'. This is unlike general Protestant theology where absolution is not practiced as forgiveness does not need to be mediated through a third party. These online confessions were devoid of evil spirit and witchcraft exorcisms, unlike the practice before the COVID-19 lockdown. In fact, much of the discourse of sin and absolution was devoid of any mention of Satan, evil spirits or witchcraft, making this practiced markedly different to that of the pre-COVID-19 church.
This article analyses this new form of online confession and absolution and argues that it has become an important agent of change for believers and their community during the crisis of COVID-19. The processes of thinking about and writing down confessions have become an agent of renewal and selfreflexivity in the lives of ordinary believers. In confession messages and testimonies, members who participate in the confessions claimed that the process enabled them to take control of their lives and declare their own personal, spiritual and social future. Whilst there are many similarities to the thesis of Weber (1930) and Foucault (1990) that confession leads to the establishment of the self-reflective autonomous individual, this article argues that this is not the full picture. Deeply related to the shaping of the individual-self through confession was the very public nature of the absolution to re-establishing the believer within the community in the context of Rabboni. These confessions act to both re-establish the individual as a changed individual and a changed 'dividual' being who is re-connected to the social and spiritual faith community through this practice. Whilst confession at Rabboni is understood as a means to end the disease of illness, poverty, addiction and broken relationships, this article does not comment on the long-term impact of confession, that is, if people were healed after confession or not. Rather it is a thematic analysis of the confessions people made over three months, between November 2020 and January 2021, during services streamed on Rabboni TV.

\section{Methodology}

Three services a week were followed, every week for the period November 2020-January 2021. At each of these services, all the confessions and testimonies were downloaded and transcribed. This came to a total of 36 confession sessions that were downloaded from the Rabboni TV YouTube channel and transcribed. Testimonies that referred to confessions or followed a confession were also downloaded and transcribed. The church usually has five services a week including Sundays. Each week two services were randomly selected so that the services focused on were not always the same two services during the week. All the Sunday services were downloaded. The transcribed confessions were then thematically analysed to bring to the fore the main themes in these confessions. Testimonies referring to confessions were also thematically analysed. It was important to analyse the testimonies and confessions over a period as people often said in testimonies how their lives had changed after making an online confession. In confessions, people also talked about how their lives had changed for some time after confessing but that they had sometimes fallen back into old behaviours and sins. The effects of the confessions are therefore verified through testimonies and later confessions.

In this article, people whose confessions were analysed are given pseudonyms, but the geographic locations they say they come from remain the same. The geographic locations are important because during COVID-19, this church has become an international church with followers from all over Africa, parts of Latin America, the Philippines and Europe. 
The research for this article is part of a broader project examining social media and Pentecostal Churches. As such, I have been watching selected online services of Rabboni church since 2018. The article begins by giving some background to Rabboni and the COVID-19 pandemic in South Africa and then examines the practice of public confession, showing how it was an agent of change in the self-understanding and self-shaping of the individual Christian and their re-establishment into the social and spiritual faith community.

Pseudonyms were used throughout.

\section{Origins and history of confession generally}

Weber (1930) argued that a critical aspect of Protestantism was its focus on the individual self's interiority, without having forgiveness mediated via a spiritual leader, thus shaping the individual modern subject. Durkheim (1912) argued that public forms of confession or ritual acts where people collectively confessed sins aloud or silently, healed social relationships and maintained social cohesion. Foucault (1990) argued that in Europe, confession, rooted in the Augustinian tradition, was central to the making of the modern self-reflexive subject. Foucault famously describes the human being as a 'confessing animal' and the West, through the wide diffusion of confession as becoming 'a singularly confessing society' (Foucault 1990:59). Tell (2009:124-129), examined the very public confession of sin given by Jimmy Swaggart on TV in 1988, argued that not all forms of confession are the same and equally rooted in Christian concepts of sin. He maintains that secular confessions, rooted in Jean-Jacques Rousseau's writing, are about staged self-disclosure of failure and not about declaring all misdeeds as sins and the individual as sinful.

Whilst the work of Murray-Swank, McConnell and Pargament (2007:275) showed that many religions (Christianity, Judaism, Buddhism, North American Native Religions) have confessional and absolution practices. Velayutham (2007:31-32) though showed that confession is not a universal human attribute as Foucault (1990) claimed. Through the analysis of written confessional material such as journals, letters, poems, and religious books, during the late Medieval and early Modern period, Cornett (2011:2-5) argued that in the Western world, confession is a learnt behaviour expressed in a particular genre and not a natural given as maintained by Foucault. Similarly absolution was a learnt and stylised practice controlled by the Catholic priesthood. Whilst confession might not be a natural human activity, work spanning over 40 years, primarily in the global North, highlights confession's therapeutic value (McKay, Herold \& Whitehouse 2013; Worthen 1974). Whilst different, in these understandings of the role of confession, scholars agree that the practice of confession together with a sense of absolution, directly from the divine or mediated through a person, is an agent of change in people's and communities' lives. In Africa, there have been three other trajectories of studies of confession and absolution that have been explored.
Maluleke (1997), August (2005) and others have looked at the societal role of the concept of confession in the Truth and Reconciliation Commission arguing that victims were problematically asked to forgive those who confessed to sins whilst the confessants were not asked to make reparations. Karanja (2016) highlighted the synthesis between confession in African religious practices and the evangelical revivals of East Africa, arguing that confession is not a 'new' concept in Africa. This is within a wider discussion of confession in Pentecostal churches, which I examine in more detail in this article. Simelane (2020) explored why private confessions made by the laity to clergy who then offer them absolution outside the context of communal confessions made during the Anglican Eucharist continue to have healing power for believers.

This article moves now to explore the new online public confession and absolution at Rabboni Church and how it has become an agent for personal change in the lives of church members during the first year of the COVID-19 crisis.

\section{Basic teaching and practice at Rabboni Rabboni Church and COVID-19 in South Africa}

The South African government declared the coronavirus a pandemic in South Africa on 24 March 2020 and the country went into a hard lockdown on 27 March 2020. For the first seven weeks of lockdown, only essential services could operate. A COVID-19 relief fund was established, but corrupt politicians embezzled much of these funds, and the money never reached the people for whom it was intended (Davies 2020). During long periods of various levels of lockdown between March 2020 and January 2021, many businesses collapsed. By January 2021, the unemployment rate in South Africa was reported to have been at a staggering $40 \%$ for several months (Engelbrecht 2020; Schüssler \& Majozi 2021). For much of 2020, government schools were closed, and the vast percentage of the school-going children who did not have access to online devices, data or electricity lost a year of schooling. In this context of poverty, rampant unemployment, disrupted education, and general uncertainty, I examine the role of public confession at Rabboni a Prophet Pentecostal Church.

When COVID-19 began, the church already had the infrastructure to move into the online space. The church quickly set up a recording studio, which looks like a living room in a wealthy home, with velvet upholstered chairs, gold ornaments and dozens of fresh flowers. At the beginning of lockdown, the services were all moved online and changed in format from the face-to-face live services before lockdown. The services between April 2020 and January 2021 were held in the studio and led by a handful of pastors. Once the church acquired Zoom, most of the pastors Zoomed into the service from home, and only two or three people were in the studio, thus modelling social distancing and avoiding contact with other people, as the government required. The services consisted of various items, which did not always follow in the same order or necessarily always form part of a service. 
Prof Daniel does not participate in each service, nor is he involved in every aspect of a service. The first part of a service was always a time of praise and worship lead by one or two musicians. Typically, the second part was a slot of teaching about the Word, usually given by one of the female pastors; this was often but not always followed by Prof Daniel's sermon. If Prof Daniel was part of the service, the sermon was usually followed by a time of prophecy. People phoned in, or Zoomed in, or emailed their requests for prophecies, and the Prophet gave his prophecies and interpretation of their dreams. During the lockdown, the session on dream interpretations became increasingly popular. Usually, this was followed by a short sermon on tithing given by one of the pastors. The next phase of the service was a lengthy time of intercessions and then a time for testimonies. These services were usually between seven and eight hours long. There were usually services on Tuesday, Wednesday, Friday, Saturday and Sunday, but sometimes there were services every day of the week. Throughout the services, a ribbon ran at the bottom of the screen, giving the church's banking details and encouraging people to tithe and pay if they want the prophet to interpret their dreams or give them a prophecy. At different times in the services, clips from earlier recordings of Prof Daniel's teachings were streamed, or prophecy sessions from in-person services at the church are aired.

Over the months of COVID-19, there have been some changes to the online services. The first was that the church introduced Zoom, and members Zoomed into the service to give testimonies, ask for prayers or have Prof Daniel prophecy over their lives. The second significant change was that the church became international, attracting people from all over Africa, Latin America, the Philippines and Europe. With this, the church's racial and economy and demography has changed to include people from all racial groups with a few people from the middle classes. Services were translated into different languages, including French and Spanish.

The third change in the service was the inclusion of public online confessions as outlined above. People must state their names and where they are from, to ensure that the confessions were not anonymous. In this article, all references to people are anonymous, as pseudonyms have been used. Prof Daniel taught about the importance of these public confessions and absolution, but he did not participate in reading out the confessions. Almost none of the confessions were confessions of witchcraft, and no deliverance from evil forces and spirits was given to followers; instead they were absolved of their sins. Whilst people did at times refer to witchcraft and unknown connections to evil forces, over $90 \%$ of the confessants did not blame witchcraft for the sins they committed. This was markedly different from the practice before lockdown where members in the congregation come forward for confession and deliverance from the Prophet after he had preached. The Prophet asked people a few questions, and they divined their sin and often referred to the forces of evil that controlled them, causing them to sin. The Prophet then exorcised these evil spirits and various demons such as the demons of adultery, anger and addiction from their lives. People were seen writhing on the floor, crying, laughing and blaspheming the Prophet as the evil spirits were driven out of their bodies. This ritual had an immediate effect, requiring little self-reflection especially as the Prophet usually diagnosed the sins and their causes. Overall, spiritual forces rather than autonomous personal actions were understood as the cause of sinful behaviours.

This type of face-to-face confession and deliverance is relatively common in PPC churches in Africa, as the research of Pype (2011) in Kinshasa, Van de Kamp (2016) in Mozambique and Badstuebner (2003) and van Wyk (2014) in South Africa shows. In Africa, it is also common to see some born-again Christians who make confessions and share their story of deliverance from witchcraft travel to various churches in a district or country (Badstuebner 2003; Pype 2011). In many churches, individuals will make public confessions of sin to the people they have harmed, and these rituals usually take place outside church services and include prayers of deliverance (Pype 2011). In the African context, Geschiere (1997) and Rowlands and Warnier (1988) showed that confessions of witchcraft function as a rhetorical discourse to express and navigate changing forms of political, cultural, religious and economic power. The public confessions of sins emailed to the church were significantly different from these face-to-face sessions, and this article will examine the consequences of this new practice and theology of confession. Before doing so, some of the dominant theoretical frameworks explaining confession and its consequences are outlined.

\section{Research findings and discussion An agent to re-established self-identity through self-agency}

During COVID-19, confession at Rabboni became understood as a profoundly self-reflective exercise and a powerful step in exercising self-agency. People reported that they were making a public confession after hearing the Prophet preach about the importance of confession or seeing 'Papa' in their dreams. Others said they had met with Pastor Queen or Pastor Elizabeth and were told to be introspective before God and then write down their sins. They were told to take their sins seriously and accept responsibility for their sinful behaviours, thoughts and feelings. This is similar to North European Protestants in the early Modern period (Weber 1930). Rabboni taught that recognising, acknowledging and writing down their sins were a crucial step in a believer's personal renewal. This echoes findings amongst contemporary Catholic, Protestant Greek Orthodox and Jewish practitioners that '(r)religious confession provides a forum for the expression of individual identity and relational needs. As a ritual that gives public sanction to personal transformation and redemption' (Hymer 1995:41).

In many of his sermons, Prof Daniel explained that Christians should not get offended by other people and should not get 
angry with other people. A Christian, through the Holy Spirit, should be able to control their emotions. The focus here is on the individual self-reflective agent who can autonomously control their emotions and whose emotions are not influenced by other spirits or other people's words, but only the Holy Spirit whom they chose to allow into their lives. A common confession from people was that they got angry or offended quickly by other people. Fikile (2021) from outside Pretoria said:

I am also confessing about offenses. I try to teach the word (at home) because my family believe so much in witchcraft, so the moment when I try to show them or teach them the word they don't pay attention so I got offended, also they criticise my church a lot and I got more offended.

She then goes on to explain the problems she has with her biological father and asks to be forgiven because she gets offended easily by her siblings with whom she shares the same mother but not father. Then she says 'Please forgive me papa every time things don't go as planned I question God' (16 January 2021). Fikile's confession is a powerful example of the centrality of the individual self. Firstly, she is selfreflective of her behaviour and actions. She owns the fact that her behaviour is wrong and that things are going wrong because she doubts God, not because there are evil forces at play. Secondly, she does not blame her actions or feelings on other people or witchcraft, even though she lives in a family where the dominant paradigm is a belief in witchcraft and she has a difficult relationship with her relatives. Thirdly, further on in her confession, she expressed how she will reshape her future, by having faith in God and not questioning Him when she faces challenges and difficulties. By confessing, she says that this sin of 'offenses' will be lifted from her, and she will once again be the sort of accepting and peaceful Christian she wants to be. For her, confession is the mechanism or agent she uses to re-establishing her Christian self-identity.

For the believers at Rabboni, the Christian self is ontologically a sinner. This was clearly expressed by one of the Apostles who emailed a confession in which he said, 'I am a sinner' (13 December 2020). He did not blame his sin on anything but his own actions and his ontological state as a member of fallen humanity. He confessed that he had tried to heal his brother without being anointed to perform healing. In the worldview of this church and its members, a believer's Christian identity as a pure and good Christian was never stable or fixed, echoing Pype's (2011) finding amongst Pentecostals in Kinshasa. The Christian self is seen as fragile and being able to live as a Christian was seen as a challenging and difficult path, which even Apostles and Pastors in the church could stray from. This was expressed in the many confessions people made about not obeying the teaching of 'Papa'. They needed to confess in order to re-establish themselves as committed Christians in an untarnished relationship with God, 'Papa' and the church. Many people confessed to not obeying 'Papa's' teaching and his instructions given in services or to them in one-on-one consultations or being critical of the Prophet and the church. Generally, these confessions were not very detailed and relatively short. These sorts of sins included not tithing, not giving a testimony when after confessing things had improved in their lives and using holy oil bought from another church. Several pastors confessed to not doing as instructed by 'Papa'. In all the confessions of this nature, people did not blame witchcraft or evil forces but claimed to be acting as self-autonomous individuals.

For all these people, their disobedience resulted in something going wrong in their lives. Bongi from Katlehong powerfully expressed this when she confessed to meeting 'Papa' and then not following his advice and 'running away from church'. Firstly, she said she lived with her baby daddy and then various other boyfriends. Now she was confessing because 'I want to return to my original state with Jesus. I am a lost child. Please forgive me, Papa please' (16 January 2021). After confessing their various sins, people usually ended with statements like that of Bongi or this one from Jimmy (16 January 2021). 'I choose Christ above all things', thus placing the self at the centre and as the agent shaping their future self through this decisive decision to choose Christ.

After confessions were read out online by one of the pastors, the pastor assured people that the Prophet absolved them of their sins and God forgave them. From the excerpts above, all the other confessions analysed people wanted absolution from both the Prophet and God. The act of confession and absolution was experienced as re-establishing the Christianself, both as an individual and as a church member. This sentiment was provocatively captured by John, a young man from Shoshanguve who had been a member of the church but then became addicted to heroin and alcohol, 'I am coming back, my Father. Without you [Prof Daniel] I am nothing' (16 January 2021).

\section{An agent to re-establish the 'dividual' being within the faith community}

It is argued that the autonomous 'modern' individual is shaped or created through hermeneutic practice and acts of narration, of which confessions are a good example (Butler 2005; Foucault 1990). In Africa, Daswani (2011), Van Dijk (2005) and Pype (2011) showed that 'the subject that emerges during confessions is far more complex and ambiguous' then Foucault argued (Pype 2011:282). Pype (2011:283) explained that the "concept of "dividuality" has come to denote a mode of personhood that perceives persons as "relational and divisible entities"'. As such people have responsibilities to other people and are connected to them emotionally and spiritually. The thematic analysis of the confessions during Rabboni online services shows that one of the most dominant themes was that people had made 'wrong connections'. 'Wrong connections' is a term used in the church referring to believers' relationships and connections with other people. The word 'connection' shows that, as in other parts of Africa, the church members did not only experience the world as individuals but also as 'dividual' beings. 
As people explained their sins, they were clear that they needed to take responsibility for their actions. However, they also acknowledged that by being with the 'wrong connections', they were influenced emotionally, spiritually and physically by those with whom they had a 'connection'. Jimmy, a man in his twenties from Limpopo, wrote that having 'been sinful connected to wrong people' he had become involved in 'doing masturbation, fornication, heavy smoking, dagga addiction and alcoholic things. I have no conscious of doing good, and I no longer pray. Papa, I am not connected to Christ' (16 January 2021). Other people had far less dramatic confessions but expressed the same sentiment. Jeremiah from Botswana confessed that through his 'wrong connections I learnt bad manners from my wrong friends' (09 January 2021). 'Wrong connections' were not only linked to being in the physical presence of people but also online relationships. Thabo from Zambia said in his confession that the 'wrong connections' he was making with people online were infiltrating his mind and his spirit. 'My mind is confused. I cannot control myself in terms of lust. My spirit is wrong' (16 January 2021).

Through 'wrong connections', people also found themselves in spiritual bondage or unable to pray or not able or willing to attend church or watch services online. Jimmy from Limpopo explained that he had lost his connection to God through wrong connections, particularly his girlfriend who prevented him from coming to church. Timothy from the Free State said that after being with his girlfriend for 10 years, she suddenly became a sangoma. Although he broke up with her, he did remain in touch with her. He realised that 'I didn't know it but I have made an agreement with the forces of darkness' (09 January 2021). This was one of the few confessions that linked sinful behaviour to witchcraft. The confession does express the churches teaching that for all believers their social interaction with people affected their spiritual lives and their ability to live as good Christians. In this church's worldview, people were understood as connected to each other.

The word 'connection' was particularly apt as the confessants all talk about being bound or connected emotionally and spiritually to others. This understanding of the socially connected (dividual) individual is best expressed in the focus on dreams. People wanted to be connected again to 'Papa' and met him in their dreams. Many people confessed and lamented that 'Papa, I don't see you anymore in my dreams' (Beauty from Soweto, 23 January 2021). Not seeing 'Papa' in their dreams was closely connected to not being able to pray or read scripture. 'Papa I need you and I want you more in my life' (Raymond from Brits 16 January 2021). Once connected again to 'Papa', they would be able to exercise the self-control and discipline he expected of his followers. They ask for freedom from the bondages of sin and to be bound again to the church, God and most importantly with 'Papa'. In this need to belong again to the faith community, there is a strong echo to the work of Durkheim (1912) on public ritual confessions where he showed how confession and forgiveness/absolution was a powerful way for social bonds to be healed and re-established.
The Prophet, as the intermediary between the believers and God, had the power to offer absolution. This has many overtones to the Catholic theology and practices. In the contemporary Catholic and Orthodox traditions, the priest is the embodiment of Christ and acts on behalf of Christ as both judge and healer (Hymer 1995:46). But, at Rabboni, this practice lies not in links to Catholicism but instead in the phenomenon of the 'Man of God-Prophet' that has been developing amongst Prophetic Pentecostal leaders in Africa over the last 10 years more generally (eds. Kgatle \& Anderson 2020) and at Rabboni church specifically (Frahm-Arp 2020). In contemporary PPC in Africa, the Prophet or Man of God is understood as the intermediary between believers and God, he is the one who is more connected to the Divine than ordinary people and therefore able to prophesy and perform miracles. He is understood to have a deeper understanding of God than other believers do and actually speaks on behalf of God. Therefore, it is not surprising that this church's theology has moved away from the Protestant conviction that no one is needed to mediate between the believer and God to a theology of mediated absolution.

For everyone who confessed, absolution from the Prophet was what they wanted. 'Papa, please forgive me' was their universal cry. Confessions ended like this one from Jimmy 'All I ask Papa is for the spirit of Christ to forgive me and for you to forgive me Papa. I plead. I choose Christ above all things' (16 January 2021). Everyone asked that the Prophet forgive them, and most, but not all, also asked God the Father and the Holy Spirit to forgive them. They all wanted to hear that the Prophet had absolved them. At the end of each confession, the pastor reading out the confessions assured the person that the Prophet and God forgave their sins, and they were now restored and renewed. The act of public confession led to the act of public absolution. Their forgiveness was publically verbalised and could be heard by them and their family and friends. There could be no doubt that they were not forgiven and restored to the community. Public confession and absolution therefore broke the 'wrong connections' or spiritual and emotional bonds and obligations with other people, which had sinfully been formed and it publically established the restoration of the confessant to be bound to 'Papa', the church and God. In a time of profound societal insecurity caused by COVID-19, the public absolution given by the Prophet offered people certainty that their sins were forgiven and they were renewed in Christ and restored to the faith community.

\section{Conclusion}

In this article, I showed how in a time of crisis, when people were not able to physically meet and build, strengthen or re-establish spiritual and emotional bonds with one another, the online public platform of confession and absolution was a powerful agent to help people navigate the challenges and social insecurities brought about by the coronavirus. As this article is focused on the written confessions of believers, it cannot comment on the effect this practice has on the church community as a whole. It does, however, show that the 
practice of confession and absolution was an agent of change in the way people understood themselves, felt empowered to take control of their lives and renewed and restored their personal and social identity. This was established by analysing the written confessions people sent in and their testimonies following confessions, which often spoke about how their lives had improved once they made a public confession and received absolution from the Prophet.

In this church, the practice of online confession during COVID-19 was a shift in the theology and practice of confession pre-COVID-19, moving away from a Prophet 'diagnosing' sin and exorcising the evil forces that caused sin, to a theology of self-reflection and personal responsibility. In this practice, the Prophet no longer exorcised evil forces immediately but rather absolved people some days after they emailed their confessions. This process helped people re-establish their individual identities as renewed, accepted, and forgiven Christians. The emphasis was on re-establishing the Christian self as no one who wrote in to confess had not been born again as a Christian at an earlier point in his or her life. In these confessions, people claimed their agency and acted as the agents of their own change by verbally claiming that no spirits or people controlled them. In a world in which their Christian-self was continually at risk of being disrupted, they were able to take measures as a self-reflective agent to manage their own spiritual and emotional state and determine their future as 'children of God' re-connected with their religious family. Deeply connected to the individual self-reflective agent was the agency of 'dividual' connection to the community. African societies are largely 'dividual' societies in which people are connected to each other through obligations and spiritual links. Public confession and absolution are seen as essential for complete forgiveness and social acceptance to take place. Because the Prophet pronounced the individual forgiven and released of the bonds of sin, this state could not be disputed by anyone. Therefore, this public absolution was a powerful agent not just in self-identity but also in the 'dividual' identity of a person as connected to the larger community of believers.

This article argues that whilst the act of narration of confession was a hermeneutic practice through which the self-reflective individual was continuously shaped, as Foucault (1990) found in Western society generally, and Weber (1930) found amongst North European Protestants, this is not the full story at Rabboni. The new practice of self-reflective examination of conscience narrated in written form played a role in the formation of self-reflective individual who was encouraged to take responsibility for their own actions. The very public nature of the confessions and absolution meant that these confessions also acted as a way in which peoples' severed connections to the faith community were re-established and they could 'come back' to 'Papa', the church and God. We see here, as Pype (2011) has shown in Kinshasa, the nuanced and complex nature of confession that not only shapes the individual but, as Durkheim (1912) showed, can also shape social bonds. This article concludes that during the COVID-19 crisis Rabboni church agley changed its theology and practice of confession and absolution, and in so doing enabled the church to operate as an agent of social change in people's lives, at a time when church practices were disrupted. People who felt hopeless, disconnected, guilty, ashamed and sinful were able to re-establish their sense of self as good Christians who were accepted into the Christian community, the Prophet and God.

\section{Acknowledgements Competing interests}

The author declares that she has no financial or personal relationships that may have inappropriately influenced her in writing this article.

\section{Author's contributions}

M.F.-A. is the sole author of this research article.

\section{Ethical considerations}

This article followed all ethical standards for research without direct contact with human or animal subjects.

\section{Funding information}

This research received no specific grant from any funding agency in the public, commercial or not-for-profit sectors.

\section{Data availability}

Data sharing is not applicable to this article as no new data were created or analysed in this study.

\section{Disclaimer}

The views and opinions expressed in this article are those of the author and do not necessarily reflect the official policy or position of any affiliated agency of the author.

\section{References}

Alexander, K.E., 2006, Pentecostal healing, Brill, Boston, MA.

August, K., 2005, 'Reconciliation in the South African political context: A challenge to the church for community building', in D. Van Keulen \& M. Brinkman (eds.), Christian faith and violence, pp. 85-105, Brill, Leiden.

Badstuebner, J., 2003, “'Drinking the hot blood of humans": Witchcraft confessions in a South African Pentecostal Church', Anthropology and Humanism 28(I), 8-22.

Butler, J., 2005, Giving an account of oneself, Fordham University Press, New York, NY.

Cornett, M., 2011, The form of confession a later medieval genre for examining conscience, University of North Carolina, Chapel Hill, NC.

Daswani, G., 2011, 'In-dividual Pentecostals in Ghana', Journal of Religion in Africa 41(3), 256-279. https://doi.org/10.1163/157006611X586211

Davies, P., 2020, 'South Africans protest as report reveals COVID-relief fund misuse', viewed 07 January 2021, from https://www.africanews.com/2020/09/03/southafricans-protest-as-report-reveals-covid-relief-fund-misuse/.

Durkheim, E., 1912, The elementary forms of the religious life, transl. J. Swain, George Allen \& Unwin Ltd., London.

ENCA, 2014, 'Grass-eating pastor now has congregation drinking petrol', viewed 04 January 2021, from https://www.enca.com/shock-scenes-grass-pastor-givinghis-congregation-petrol-drink.

Engelbrecht, N., 2020, 'South Africa's unemployment rate increases', viewed 07 January 2021, from https://www.enca.com/business/south-africas-unemployment-rateincreases. 
Foucault, M., 1990, The history of sexuality, volume 1: An introduction, Vintage, New York, NY.

Frahm-Arp, M., 2020, 'Pneumatology and prophetic Pentecostal Charismatic Christianity during COVID-19 in South Africa', in M. S. Kgatle \& A. H. Anderson (eds.), The use and abuse of the spirit in Pentecostalism: A South African perspective, pp. 150-174, Routledge, London.

Geschiere, P., 1997, The modernity of witchcraft, University Press of Virginia, Charlottesville, VA.

Hymer, S., 1995, 'Therapeutic and redemptive aspects of religious confession', Journa of Religion and Health 34(1), 41-54. https://doi.org/10.1007/BF02248637

Karanja, J., 2016, 'Confession and cultural dynamism in the revival', in K. Ward \& E. Wood (eds.), The East African revival, pp. 159-168, Routledge, London.

Kgatle, M.S. \& Anderson, A.H. (eds.), 2020, The use and abuse of the spirit in Pentecostalism: A South African perspective, Routledge, London.

Maluleke, T.S., 1997, 'Truth, National Unity and reconciliation in South Africa: Aspects of the emerging agenda', Missionalia 25(1), 59-86.

McKay, R., Herold, J. \& Whitehouse, H., 2013, 'Catholic guilt? Recall of confession promotes prosocial behavior', Religion, Brain \& Behavior 3(3), 201-209. https:// doi.org/10.1080/2153599X.2012.739410

Murray-Swank, A.B., McConnell, K.M. \& Pargament, K.I., 2007, ‘Understanding spiritual confession: A review and theoretical synthesis', Mental Health, Religion \& Culture 10(3), 275-291. https://doi.org/10.1080/13694670600665628

Pype, K., 2011, 'Confession cum deliverance: In/individuality of the subject among kinshasa's born-again Christians', Journal of Religion in Africa 41(3), 280-310. https://doi.org/10.1163/157006611X586202
Rowlands, M. \& Warnier, J.-P., 1988, 'Sorcery, power and the modern state in Cameroon', Man 23(1), 118-132. https://doi.org/10.2307/2803036

Schüssler, M. \& Majozi, P., 2021, 'Level 3 restrictions will cost one in 12 South Africans their jobs', Moneyweb, viewed 30 January 2021, from https://www.moneyweb. co.za/news/economy/level-3-restrictions-will-cost-one-in-12-south-africans-theirjobs.

Simelane, M.W., 2020, 'Confidentiality of private confessions made to priests: A perspective from the Anglican Church in South Africa', Doctoral dissertation, North-West University.

Tell, D., 2009, 'Jimmy Swaggart's secular confession', Rhetoric Society Quarterly 39(2), 124-146. https://doi.org/10.1080/02773940902766748

Van de Kamp, L., 2016, Violent conversion: Brazilian Pentecostalism and urban women in Mozambique, Boydell \& Brewer, Suffolk.

Van Dijk, R., 2005, 'The normal life of the gift in Ghanian Pentecostal churches in the diaspora: Questions of (in) dividuality and (in)alienability in transcultural reciprocal relations', in W. van Binsbergen \& P. Geschiere (eds.), Commodification: Things, agency, and identities, pp. 201-224, Münster Lit., Münster.

Van Wyk, I., 2014, The universal church of the Kingdom of God in South Africa: A church of strangers, Cambridge University Press, Cambridge.

Velayutham, S., 2007, 'The contribution of the practice of confession and the protestant reformation to the modern practice of accountability', Corporate Governance 7(1), 29-40. https://doi.org/10.1108/14720700710727096

Weber, M., 1930, The protestant ethic and the spirit of capitalism, Routledge, London.

Worthen, V., 1974, 'Psychotherapy and catholic confession', Journal of Religion and Health 13(4), 275-284. https://doi.org/10.1007/BF01534226 